\title{
Kernos
}

Revue internationale et pluridisciplinaire de religion grecque antique

9 | 1996

Varia

\section{Conflicting Authorities. Asylia between Secular and Divine Law in the Classical and Hellenistic Poleis}

\section{Angelos Chaniotis}

\section{(2) OpenEdition}

Journals

Electronic version

URL: http://journals.openedition.org/kernos/1157

DOI: 10.4000/kernos. 1157

ISSN: 2034-7871

\section{Publisher}

Centre international d'étude de la religion grecque antique

Printed version

Date of publication: 1 January 1996

ISSN: 0776-3824

\section{Electronic reference}

Angelos Chaniotis, «Conflicting Authorities. Asylia between Secular and Divine Law in the Classical and Hellenistic Poleis », Kernos [Online], 9 | 1996, Online since 21 April 2011, connection on 19 April 2019. URL : http://journals.openedition.org/kernos/1157 ; DOI : 10.4000/kernos. 1157 


\section{Conflicting Authorities.}

\section{Asylia between Secular and Divine Law in the Classical and Hellenistic Poleis}

\section{Conflicting authorities: The problem ${ }^{1}$}

As the story goes (Hdt., I, 157-159), in the late 6th century the Lydian Paktyes had taken refuge as a suppliant in Kyme after an unsuccessful revolt against the Persians. Upon the demand of the Persians to hand him over, Kyme asked the oracle at Didyma how to deal with Paktyes in the way most likely to win the favour of the god. The surprising answer was to deliver him to the Persians. A second embassy was sent to the oracle and its spokesman repeated the question, adding that, in spite of their fear of Persian power, the Kymeans did not dare to follow the initial instructions until they might receive from Apollon clear instructions upon how they should act. Yet, the answer remained the same. Upon this, the envoy Aristodikos went all round the outside of the temple driving away the birds which had built their nests there; while he was doing it, he heard a voice from the adyton saying: "Most impious among men, how dare you do this wicked thing? Would you carry off the suppliants (

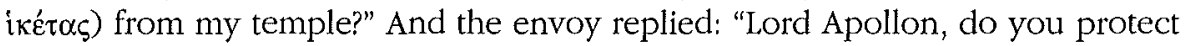
your suppliants, yet tell the men of Kyme to abandon theirs ?" "Yes," answered the god; "I do indeed, that you may suffer the sooner for your impious deed ( $\dot{\alpha} \sigma \varepsilon \beta \eta \dot{\sigma} \sigma \nu \tau \varepsilon \varsigma$ ), and never come here again to consult my oracle about handing over suppliants." As very often in ancient religions, a seemingly inconsistent behaviour of the deity turns out to be a test of the mortals' morality and faith. Thus the divine message becomes even more clear: Suppliants either in a city or in a sanctuary should be protected at all events, no matter what has caused them to seek protection.

Now another story. In Euripides' Ion Kreousa has attempted to poison Ion, not knowing that he was her own son. Asking the chorus where to run and find refuge (1. 1250-1260), she is advised to run to the altar, since it is impious to

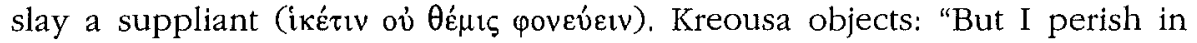

1 This paper was presented at the Colloquium in Athens and in lectures in Heidelberg and Basel. I am very greatful to many auditors for their comments, especially to Professors Fritz Gschnitzer (Heiderberg) and Michael Peachin (New York, who has also improved the English text substantially). All dates are B.C., if not indicated otherwise. 


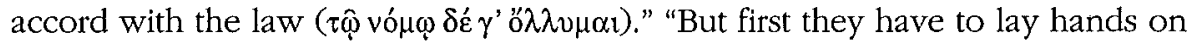
you," replies the chorus. "Upon the altar take your seat. For, if they slay you here, your blood will call to heaven for vengeance on the murderers." For this reason her pursuer, Ion, makes the earliest attack against the institution of asylia in the Greek literary tradition (1. 1312-1320): ' 'Shame that a god ordained bad laws for mortals, statutes not in wisdom framed! Never should unrighteous persons sit on altars, but they should be hounded thence. Unmeet is that hands sin-stained should touch the gods. But righteous men, whoever was wronged, should claim their sanctuary, and not the good and evil come alike hither to win the same boon of the gods" (translation of Arthur Way, partly changed). The distinction between the secular nomos which condemns the assailant and the divine themis which protects the suppliant, regardless of the crime he has committed, is clear; equally clear is Ion's condammation of this indifference of the divine law towards the suppliants, righteous and unrighteous alike. ${ }^{3}$

Despite the obvious differences between the two stories, the moral is still the same: Divine law recognizes no limits in the protection of suppliants. For the shake of convenience I will call this protection asylia, although this term can be used with a variety of meanings in the ancient sources, from the inviolability of every sanctuary and the personal inviolability of an individual guaranteed by a foreign city, to the prohibition of reprisals agreed upon by two communities, or the inviolabiliy of certain sanctuaries recognized by kings, cities, and confederations. ${ }^{4}$ In this paper I shall refer exclusively to the inviolability of every sanctuary, a right probably as old as the sanctuaries themselves. When a suppliant is harmed or dragged out of the sanctuary, this action (sylan) resembles the theft of divine property; the violation of asylia is bierosylia. ${ }^{5}$ By

2 Cf. P. STENGEL, s.v. Asylon, in RE, II. 2 (1896), c. 1882; H. BOLKESTEIN, Wobltätigkeit und Armenpflege im vorcbristlicben Altertum, Utrecht, 1939, p. 247f.; J. MIKALSON, Honor Tby Gods: Popular Religion in Greek Tragedy, Chapel Hill-London, 1991, p. 75; U. SINN, Greek Sanctuaries as Places of Refuge, in N. MARINATOS - R. HÄGG (eds.), Greek Sanctuartes: New Approacbes, London-New York, 1993, p. 108 n. 11.

3 On this passage see A.P. BURNETT, Human Resistance and Divine Persuasion in Euripides' Ion, in CPb, 57 (1962), p. 99 with n. 36; she points out that Euripides keeps his distance from Ion's criticism (see infra, the end of my article); $c f$. MIKALSON, op. cit. (n. 2), p. 75 with n. 33. Similar criticism also in EURIP., Herakl., 259; Oedipus, fr. $1049 \mathrm{~N}$ (infra, n. 14).

4 On the various notions of asylia see F. VON WOEß, Das Asylwesen Ägyptens in der Ptolemalerzelt und die spattere Entwicklung, München, 1923, p. 4f.; E. SCHLESINGER, Die griechiscbe Asylie, Giessen, 1933, p. 2-6, 28-38, 53-71; L. WENGER, s.v. Asylrecht, in RAC, 1 (1950), p. 837f.; D. VAN BERCHEM, Trois cas d'asylie archaique, in $M H, 17$ (1960), p. 21-33; Ph. GAUTHIER, Symbola. Les étrangers et la justice dans les cltés grecques, Nancy, 1972, p. 209-284, esp. 209-226, 226-230; B. BRAVO, Sulân. Représallles et justice privée contre des étrangers dans les cités grecques, in ASNP, 10 (1980), p. 747-750; U. SINN, Das Heraion von Peracbora. Eine sakrale Scbutzzone in der korintbiscben Peraia, in MDAI(A), 105 (1990), p. 71f; MIKALSON, op. cit. (n. 2), p. 69-77 (asylum in Athenian tragedy); SINN, art. cit. (n. 2), p. $90 \mathrm{f}$.

5 SChLESINGER, op. cit. (n. 4), p. 30-33; GAUTHIER, op. cit. (n. 4), p. 226; MIKALSON, op. clt. (n. 2), p. 73 with n. 16. 
coming into physical contact ${ }^{6}$ with a sacred place the suppliant is somewhat incorporated in the sanctity of the place, becoming in a sense property of the god. "I give my body as sacred property to the god to have," as Kreousa puts it

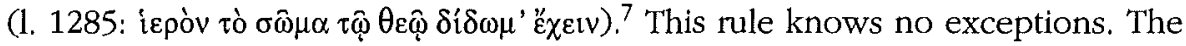
altar is an "unbreakable shield, stronger than a fortification wall", the "abode of the gods a protection common to all men", to use the words of Aischylos (Hiket., 190) and Euripides (Herakl., 260) respectively. ${ }^{8}$ Considerations of sin, guilt, right, and justice have no bearing on the claim of a suppliant to remain in the sanctuary or to be delivered to his pursuers. In Euripides' Herakleidai (1. 236-246) the Athenian king Demophon presents the reasons for accepting the suppliants, who had taken refuge in the sanctuary of Zeus Agoraios: kinship, the obligation to repay a good service, the personal and political shame of Athens, respect to Zeus' altar. ${ }^{9}$ Demophon makes no allowance for whatever may have caused the Herakleids to seek asylum. Beside the evidence of Athenian drama, collected and discussed recently by J. Mikalson (note 2), this attitude is confirmed by legal sources. Lysias, e.g., describing how the 30 tyrants in Athens siezed their victims from the altars, comments: "Because of their

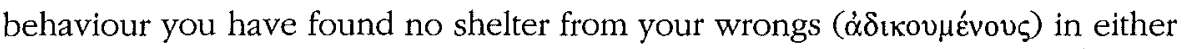
temples or altars, which save even the wrongdoers ( $\tau$ oiิ $\dot{\alpha}^{\delta} \delta$ เ question of morality and justice is not raised in the extant leges sacrae on supplication. ${ }^{11}$ A decree of Tralleis, confirmed in the 4 th century by a Persian

6 On the ritual of supplication see J. GOULD, Hiketela, in JHS, 93 (1973), p. 74-103, esp. 75-85; cf. SCHLESINGER, op. cit. (n. 4), p. 32-36; SINN, art. cit. (n. 4), p. 73-75; MIKALSON, op. cit. (n. 2), p. 72 with notes 8 and 9; SINN, art. cit. (n. 2), p. 88-92; W. PÖTSCHER, Die Struktur der Hikesie, in WS, 107/108 (1994-1995), I, p. 51-75 (= Sphairos. Hans Schwabl zum 70. Geburtstag gewidmet).

7 SCHLESINGER, op. cit. (n, 4), p. 33; GAUTHIER, op. cit. (n. 4), p. 226; MiKAlSON, op. cit. (n. 2), p. 73 with n. 14 .

8 On the unlimited character of asylia see SCHLESINGER, op. cit. (n. 4), p. 2, 52; cf. H. LLOYDJONES, The Justice of Zeus, Berkeley-Los Angeles-London, $1983^{2}$, p. 5 and 30 (on Zeus Hikesios); MIKALSON, op. cit. (n. 2), p. 76.

9 MIKALSON, op. cit. (n. 2), p. 71 and 257 n. 5.

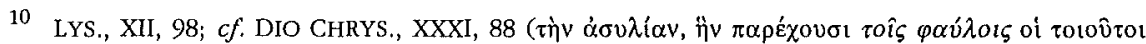

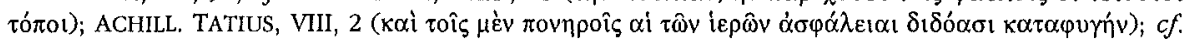
SINN, art. cit. (n. 2), p. 108. Notice, however, that respect for the asylum does not mean that any (further) request of the suppliant would be automatically accepted (MIKALSON, op, cit. [n. 2], p. 72).

11 On the 'cathartic law' of Lindos ( $S E G$, XXXIX, 729; 3rd century) and two related texts from Kyrene (LSS, 115 B 29-59; 4th century) and Selinous (M.H. JAMESON - D.R. JORDAN - R.D. KOTANSKY, A Lex Sacra from Selmous, Durham, 1993 (GRBS Monographs, 11), p. 8-17; mid-fifth

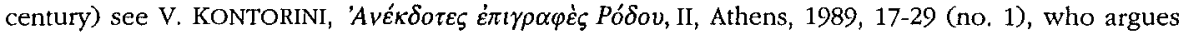
convincingly that the ixéoı mentioned in the 'cathartic law'. of Kyrene are suppliants, and not visitants or hostile spirits ( $c f$. the recent discussion of the Kyrenean law by R. PARKER, Miasma: Polllution and Purification in Early Greek Religion, Oxford, 1983, p. 347-351 with the older bibliography; $c f$. now Chr. A. FARAONE, Talisman and Trojan Horses: Guardian Statues in Greek Myth and Ritual, New York-Oxford, 1992, p. 81f.); the latter view is still adopted by JAMESONJORDAN-KOTANSKY, op. cit, p. 54-57, 116-120, who interpret the respective passages of the leges sacrae of Selinous and Kyrene as related to visitants; however, they do not exclude the possibility 
king, establishing the asylia (inviolability) and biketeria (the right to accept suppliants) of the sanctuary of Dionysos Bakchios, protects the iviolability of every suppliant, regardless of the reason he sought divine protection: ${ }^{12}$ "Nobody should wrong a suppliant... Nobody should either wrong a suppliant or remain indifferent when he sees a suppliant beeing wronged; otherwise let him and his whole stock be destroyed."

The blind and indifferent application of this rule might clearly lead to problems. The presence of suppliants in a sanctuary could easily jeopardize a city's safety, since criminal elements and persons willing to do anything in their despair could be among them; even if the fugitives were innocent victims of injustice their presence in a city would provoke their pursuer's enmity. ${ }^{13}$ This phenomenon could also undermine the political authority and the authority of secular law: Can a community tolerate that native and foreign murderers, thieves, runaway slaves, traitors, and debtors find safety, impunity, or release from the burden of their debts in a sanctuary? And if runaway slaves had some justification for their escape, claiming to be the victims of cruel treatment, what about already convicted criminals, found guilty by secular courts, as was the case of Kreousa, convicted for her crime (1. 1251: $\left.\psi \dot{\eta} \varphi \omega \kappa \rho \alpha \tau \eta \theta \varepsilon i \sigma^{\prime}\right)$, but safe in the god's adyta. Ion's criticism is not unique. In Euripides' lost tragedy Oedipus (fr. $1049 \mathrm{~N}$ ) an anonymous speaker in an unknown context expresses the same conflict between secular authority (the authority of a court) and the divine law protecting, invariably, asylia: "When a man who is unjust sits at an altar, I would bid the tradition farewell and, not fearing the gods, would take him off to court. A bad man ought always to suffer badly". ${ }^{14}$ Until the 2 nd century A.D. similar accusations are not uncommon in the literary sources, especially in relation to the sanctuaries of Asia Minor (e.g., the Artemision at Ephesos), where according

that these leges sacrae may concern the purification of homicides (p. 57f.). For Ptolemaic Egypt see VON WOEß, op. cit. (n. 4), p. 171.

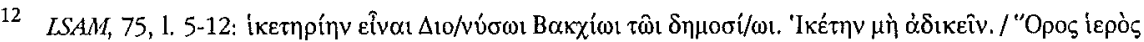

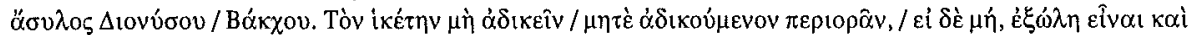

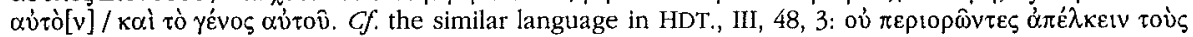

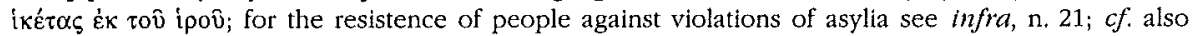

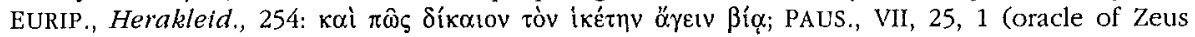

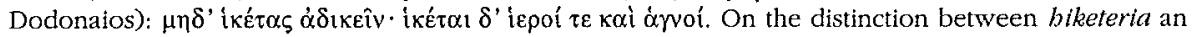
asylia (esp. in hellenistic times) see, e.g., VON WOEß, op. cit. (n. 4), p. 74; P. DEBORD, Aspects sociaux et économiques de la vie religleuse dans l'Anatolie gréco-romaine, Leiden, 1982 (EPRO, 88), p. 285.

13 For criminals in sanctuaries see infra, n. 15. For the problems in the Samian Heraion (infra, 54) see F. SOKOLOWSKI, The ká $\pi \eta \lambda$ ot in the Heraion of Samos, in ZPE, 29 (1978), p. 144f.; L. SOVERINI, Il "commercio nel tempio": Osservazioni sul regolamento dei kapeloi a Samo (SEG $X X V I$, 545), in Opus, 9-10 (1990-1991), p. 75-77, 84. For supplication provoking the pursuer's attack see, e.g., the aforementioned story of Paktyes and the evidence in Attic drama: SCHLESINGER, $o p$. cit. (n. 4), p. 41-43; M. OSTWALD, From Popular Sovereignty to the Sovereignty of Law, BerkeleyLos Angeles-London, 1986, p. 141-145; MIKALSON, op. cit. (n. 2), p. 71; cf. SINN, art. cit. (n. 2), p. 92. 
to Strabo, Tacitus, and Plutarch all kinds of criminal elements, runaway slaves, and debtors found refuge. ${ }^{15}$

This inherent conflict between divine and secular authority became increasingly apparent as and wherever the state institutions grew and developed, and the solution of legal conflicts became less a matter of private reprisals and arbitration and more an issue of public courts. Athenian drama often reflects this conflict between secular and religious authority, Sophokles' Antigone being the best known play with such a theme, but hardly the only example. ${ }^{16}$ Here, asylia will present a case study for this kind of conflicts. This particular issue was not a conflict between magistracies, since in the Greek polis no sharp distinction between secular and religious offices existed, the priests being in most cases elected officials of the community. It was primarily a conflict between an unwritten custom, transmitted from generation to generation and regarded as a divine command, on the one hand, and legal regulations introduced in a relatively late period, on the other. The evidence quoted so far shows that the Greeks had realized the problem, whose dimensions should not be underestimated. As Ulrich Sinn has recently demonstrated, we must assume that from the classical period on large numbers of suppliants ran to Greek sanctuaries and sometimes remained there for a long time, so that installations for their lodging became necessary. ${ }^{17}$ This paper, however, concerns itself with the

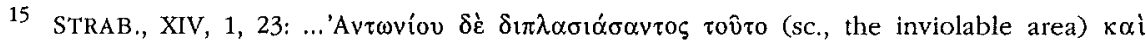

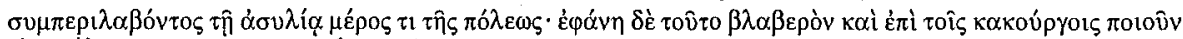

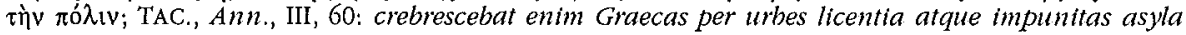
statuendi; complebantur templa pessimis servitorum; eodem subsidio obaerati adversum creditores suspectique capitalium criminum receptabantur, nec ullum satis validum imperium erat coercendis seditionibus populi flagitia bominum ut caerimonias deum protegentis; PLUT.,

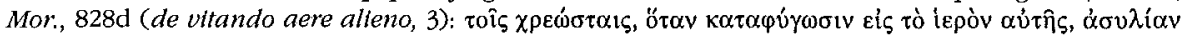

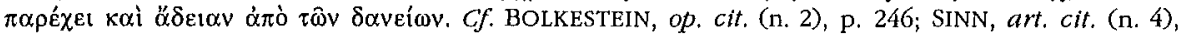
p. 108; H. ENGELMANN, Beitragge zur ephesischen Topographie, in ZPE, 89 (1991), p. 295 (on APOLL. TYAN., I, p. 363 ed. KAYSER). Similar accusations in Ptolemaic Egypt: VON WOER, op. cit. (n. 4), p. 137, 140, 171-174; see esp. BGU, VI, $1212 \mathrm{C}=$ M.-T. LENGER, Corpus des ordonnances des Ptolémées, Bruxelles, 1964 , p. 222-225, no. 82 (measures of Ptolemy IV Philopator against the exploitation of asylia for the purpuse of $\alpha \delta \omega \sigma t \delta \kappa^{\prime} \alpha$ ); on this text see VON WOEß, op. cit. [n. 4], p. 1921, 119f.); in imperial times: Th. PEKÁRY, Das römiscbe Kaiserbildnis in Staat, Kult und Gesellschaft dargestellt anband der Scbrtftquellen, Berlin, 1985, p. 130f. (with bibliography).

16 See, e.g., OSTWALD, op. cit. (n. 13), p. 137-171, ; MIKALSON, op. cit. (n. 2), esp. 69-131.

17 SINN, art. cit. (n. 4), p. 53-116, esp. 67-69, 77, 83-97, 106-110; SINN, art. cit. (n. 2), p. 88-109 (measures for the lodging of suppliants); cf. MIKALSON, op. cit. (n. 2), p. 70 f. and 257 n. 2 (fifthcentury episodes involving asylum). For Ptolemaic Egypt see L. DELEKAT, Katoche, Hierodulie und Adoptionsfreilassung, München, 1964, p. 48-85. According to a restoration of a decree of Kastabos (P.M. FRASER - G.E. BEAN, The Rbodian Peraia and Islands, London, 1954, p. 24-27, no. 15, 2nd century) proposed by J. COOK - W.H. PLOMMER, The Sanctuary of Hemithea at Kastabos, Cambridge, 1966, p. 65, the sanctuary of Hemithea took measures for the lodging of biketai (1. 3-4):

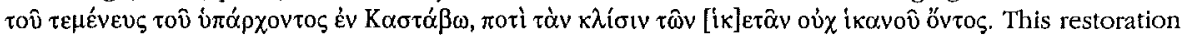
is, however, not certain, $[\delta \alpha \mu] \varepsilon \tau \hat{\alpha} v,[\varphi v \lambda] \varepsilon \tau \hat{\alpha} \nu$ et. sim. being possible alternatives; besides, the word biketes can also mean the pilgrim, in general. For this text and the proposed restorations see now W. BLÜMEL, Die Inschriften der rbodiscben Peraia, Bonn, 1991 (Inscbr. griech. Stadte aus Kleinasien, 38), p. 110f. no. 401; A. BRESSON, Recueil des inscriptions de la Pérée rhodienne (Pérée intégrée), Paris, 1991, p. 68-72 no. 44. 
measures Greek poleis took not in order to provide lodging to suppliants, but in order to get rid of them.

The epigraphic and literary evidence assembled here ${ }^{18}$ shows that the Greeks tried in many ways to escape from the embarassing situation of people evading the grasp of secular law by appealing to an old and unalterable tradition. In the changing world of the archaic polis the idea of unlimited asylia presented a relic of an old notion of guilt, for which intention and planning played no rôle and only the concrete deed counted. This idea was difficult to accomodate with a new concept of justice which prevailed increasingly from the late 7 th century. The introduction of a new, differentiated notion of guilt, which distinguished between intention and accident, had significant effects on two central areas of ancient religiosity, i.e., asylia and miasma. Asylia on the one hand was increasingly regarded as the right of victims of injustice; for miasma, not only the deed, but also the thought became increasingly important. Yet, despite these tendencies and developments the persistence of sacred law prevented the formulation of clear, unequivocal, generally applicable rules for the acceptance or rejection of claims of supplication. This conflict of authority was not solved after all. In this paper I concentrate on the world of the Greek poleis, leaving aside Hellenistic or Roman regulations, where the problem was seen in a different way due to the different structures of power and the different traditions. ${ }^{19}$

The most obvious solution was of course simply to violate asylia, hoping that the gods would turn a blind eye to the violation, especially if the pursued person was clearly a criminal. After all, the gods were the only guarantors of asylia. Until the Hellenistic age there is no evidence for a legal procedure against persons who had violated asylia. ${ }^{20}$ Given the lack of a legal protection

18 I know of no comprehensive collection and discussion of the relevant sources. References to part of the evidence are found in many discussions of the subject of asylia and supplication, e.g., K. LATTE, Heiliges Recht. Untersuchungen zur Geschichte der sakralen Rechtsformen in Griechenland, Tübingen, 1920, p. 107f,; Chr. HABICHT, Samische Volksbeschlitsse der bellentistischen Zeit, in $M D A I(A), 72$ (1957), p. 229 (treatment of suppliant slaves); G. THÜR - H. TAEUBER, Prozeßrechtlicher Kommentar zur "Kramerinschrift" aus Samos, in Anzeiger Akad. Wien, 115 (1978), p. 214f., 219-221; KONTORINI, op. cit. (n. 11), p. 19 n. 10; SINN, art. cit. (n. 2), p. 92f., 95; SOVERINI, art. cit. (n. 13), p. 106, n. 202-204.

19 On Ptolemaic Egypt see VON WOEß, op. cit. (n. 4), esp. p. 12-25, 92-104 (on the 'AsylieKlausel' found in contracts, with which the borrower promised not to seek asylum if unable to repay the debt), 62-74 (on the ' $\alpha \gamma \omega \dot{\gamma} \gamma \mu_{0}-\mathrm{Klausel}$ '), 171-174 (on the exemption of debitores publict); for the significance of the local, pre-Ptolemaic element see VON WOEß, op. ctt. (n, 4), p. 33-47. For measures limiting the right ad statuas confugere in the Roman Empire see VON WOEß, op. cit.

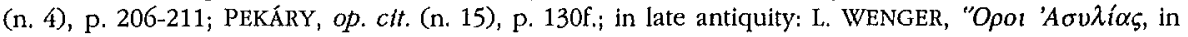
Philologus, 86 (1931), p. 427-454; WENGER, art. cit. (n. 4), p. 841 f.

20 The classical and many later leges sacrae about asylia and supplication leave the protection

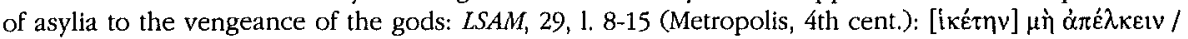

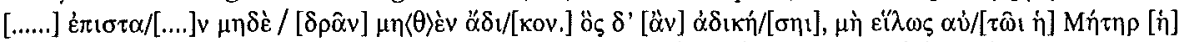

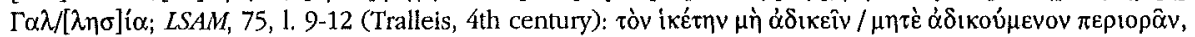

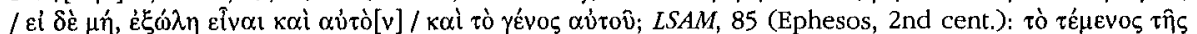

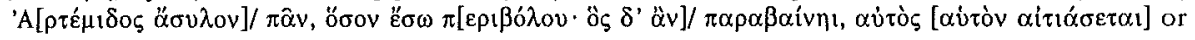


of asylia, stories about the violent removal of suppliants from altars and sanctuaries are not uncommon, but our sources never neglegt to stigmatize these instances of sacrilege and to interpret any misfortune that befell the violator in the future as expression of the divine anger. ${ }^{21}$ If the victims of the violation happened to be innocent, this only made things worse; but the violation of asylia was condemned even if the suppliants were convicts or criminals. Equally common as the violation of asylia is the effort to get around it deceitfully, e.g., by interrupting the physical contact between the suppliants and the sacred place or by forcing the suppliants to leave the sanctuary by burning them out, walling them up, prohibitting their food supply, or simply promising to give them a fair trial or guarantee a safe departure and then seizing and killing them. ${ }^{22}$ Sometimes, negotiations served both parties, securing for the suppliants, especially debtors, a better treatment, and permitting the authorities to save face. ${ }^{23}$ One of these methods, the prohibition of food supply (especially to runaway slaves), was institutionalized in some sanctuaries in the Hellenistic age, i.e., in Andania and Samos ( $\$ 4$ and note 58).

True, it was often easier to apply tricks than to introduce clear legal limitations of asylia. Despite the fact that the Greeks were conscious of the problem that asylia could be exploited by criminal elements and despite the occasional criticism, they were extremely reluctant to introduce clear, direct, and unambiguous limitations. The documentary evidence reveals basically three ways to

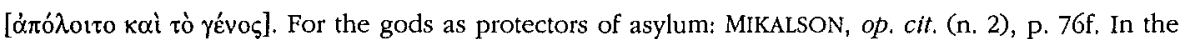
Hellenistic period the violation of asylia could be prosecuted as sacrilege: see, e.g., LSS, 158, 1. $2 \mathrm{f}$. (Kos, 3rd cent.); I.Cret., II, iii 2 l. 48f.; GAUTHIER, op. cit. (n. 4), p. 268f. (Pergamon, 2nd cent.); vON WOEß, op. cit. (n. 4), p. 110, cf. p. 106f. (Ptolemaic Egypt). PLAUT., Rudens, 839-891 implies prosecution for violation of an asylum (1. 839f.: violentia de ara decipere Veneris voluit). Also violators of the Lindian 'law on suppliants' were prosecuted for hierosylia; SEG, XXXIX, 729, 1. 7-12; see KONTORINI, op. cit. (n. 11), p. 26. The hellenistic evidence usually concerns the asylia explicitly granted to certain sanctuaries and recognized by kings and foreign communities; on this type of asylia see GAUTHIER, op. cit. (n. 4), p. 226-230.

21 For testimonia and discussion see, e.g., STENGEL, art. cit. (n. 2), c. 1882; SCHLESINGER, op. cit. (n. 4), p. 33f.; J. MIKALSON, Atbentan Popular Religion, Chapel Hill-London, 1983, p. 99; SINN, art. cit. (n. 4), p. 78f., 109f.; MIKALSON, op.cit. (n. 2), p. 69f., 72f., 75; SINN, art. cit. (n. 2), p. 93. On violations of asyla in Ptolemaic Egypt see the testimonia in VON WOEß, op. cit. (n. 4), p. 8f., 137-139,

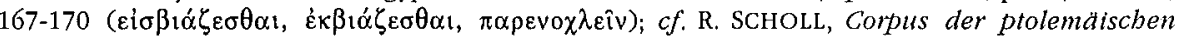
Sklaventexte, Stuttgart, 1990, I, p. 303. For the outrage or even the resistence of people and priests against violations of asylia see VON WOEß, op. cit. (n. 4), p. 90-92; a nice example is found in PLAUT, Rudens, 615-705 (citizens of Kyrene defend two suppliant girls); $c f$. ACHILL. TATIUS, VIII, 2-3 and supra, n. 12.

22 See esp. SINN, art. cit. (n. 4), p. 78-80, 97, 110f. Examples from Attic tragedy: MIKALSON, op. cit., p. 73 with notes 17-18. Further examples: STENGEL, art. cit. (n. 2), c. 1882; DELEKAT, op. cit. (n. 17), p. 60f.; GOULD, art. cit. (n. 6), p. 82f. See esp. the inscription from the Samian Heraion discussed below (\$4).

23 See, e.g., THUC., III, 70, 5; cf. DEMOSTH., 18, 107; BOLKESTEIN, op. cit. (n. 2), p. 246. A characteristic case of negotiations is reported in an inscription from Seuthopolis (early 3 rd century?). It contains the oath of Berenike and her sons, who guaranteed the safe departure of a suppliant from the sanctuary of the Samothrakian gods: IGBulg., III 2, 1731; see the new edition and commenary of K.-L. ELVERS, Der "Eid der Berenike und ibrer Söbne": eine Edition von IGBulg. III 2, 1731, in Chiron, 24 (1994), esp. p. 252-261. 
deal with the problem: a) by prohibiting persons most likely to seek asylum, e.g., convicted and polluted persons, from entering a sanctuary in the first place $(\$ 2)$; b) by having measures against suppliant wrongdoers confirmed by the gods through oracles $(\varangle 3)$; and $c$ ) by conferring on the religious personnel the authority to expell suppliant slaves $(\$ 4)$.

\section{Prohibitions against unwelcome intruders in sanctuaries

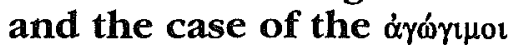

The evidence for measures excluding from sanctuaries persons who might try to escape the grasp of law is primarily Attic. A fragmentary Attic decree (ca. $432 / 1$ ) related to works on the Acropolis ${ }^{24}$ provides for the building of a wall, so that neither runaway slaves nor thieves could enter the sanctuary (hó $\pi[0 \varsigma] \ddot{\alpha} v$

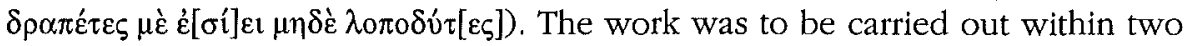
months, and three archers were to be set there as guards. Already H.W. Lolling has pointed out that the runaway slaves and thieves were to be kept out of the Acropolis, so that they would not seek asylum there ${ }^{25}$ We should notice the silence of this decree as to the fate of fugitives and criminals, who did manage to get into the sanctuary. Were they beyond the responsibility of the Athenian authorities, or were at least the priests allowed to expell these intruders from the sanctuary (see infra $\$ 4$ )?

As we may infer from Attic forensic speeches some categories of convicts were excluded from sanctuaries. It should be underlined here that these provisions aimed primarily at protecting the sanctuaries from pollution, and not at prohibiting the exploitation of asylia. Andokides makes an allusion to an Attic law which forbade persons convicted as atimoi to enter sanctuaries. Death

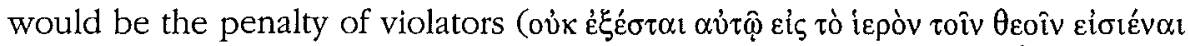
î $\alpha \pi \circ \theta \alpha v \varepsilon i \tau \alpha \mathbf{i})$; obviously, supplication could not save them. ${ }^{26}$ A similar impediment is mentioned in Lysias' speach against Andokides (VI, 24). A decree passed by the Athenians provided that Andokides was to be barred from the marketplace and the temples, so that even if wronged by his enemies he

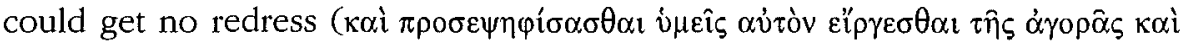

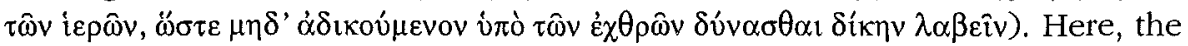
ad hoc regulation aimed at depriving Andokides from the protection of asylia. Analogous laws prohibited men who failed to take the field, deserters, coward men, and women engaged in adultery to enter public sanctuaries. ${ }^{27}$

$24 I G, \mathrm{I}^{3}, 45\left(I G, \mathrm{I}^{2}, 44\right)$.

25 Cf. LATTE, op. cit. (n. 18), p. 107; SINN, art. cit. (n. 4), p. 79; SINN, art. cit. (n. 2), p. 92.

26 ANDOK., 1, 33; cf. D. MACDOWELL, The Law in Classical Athens, London, 1978, p. 73F.

27 [DEMOSTH.], 59, 87; AISCH., 3, 177. Cf. A.R.W. HARRISON, The Law of Athens. The Family and Property, Oxford, 1968, p. 36; MIKALSON, op. cit. (n. 21), p. 99; MACDOWELL, op. cit. (n. 26), p. 125. 
Analogous regulations can be found outside Attica. Narrating one of the attrocities in Sparta after the death of Kleomenes, the butchering of ephors in the sanctuary of Athena Chalkioikos, Polybios ${ }^{28}$ stretches the fact that this particular sanctuary secured the safety even of persons condemned to death

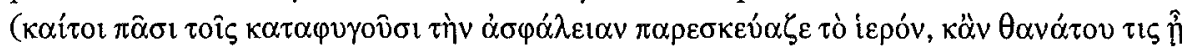
$\kappa \alpha \tau \alpha \kappa \varepsilon \kappa \rho \mu \varepsilon \dot{v o \varsigma}$ ), thus indicating that this was not the general rule. ${ }^{29}$ There were obviously some sanctuaries, at least at his time, which did not offer safety to persons condemned to death. We should mention in this context the amphictionic decree of 346/45 against the defeated Phokians after the Third Sacred War, according to which the fugitive Phokians as well as any other person who had participated in the plundering of the sanctuary were to be arrested

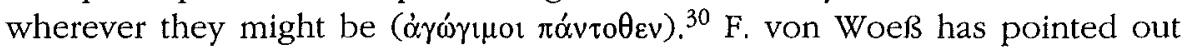
that in the Ptolemaic documentary material the word $\dot{\alpha} \gamma \dot{\omega} \gamma i \mu \operatorname{s}_{5}$ is used as a synonym of 'deprived of asylia' ("auch ohne Asylschutz") and assumed that this clause aimed at depriving the persons involved in the Delphic sacrilege from the protection of asyla. ${ }^{31}$ This is, however, not certain. The same clause is found in the decree proposed by Aristokrates for the mercenary leader

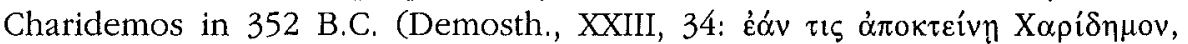

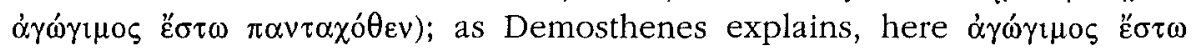
$\pi \alpha v \tau \alpha \chi o^{\prime} \theta \varepsilon v$ means liable to seizure elsewhere than in Athenian territory (XXIII,

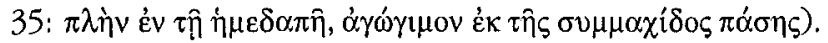

In the light of these regulations, we may understand properly a Hellenistic lex sacra from Eresos concerning itself with ritual purity. ${ }^{32}$ The text lists the

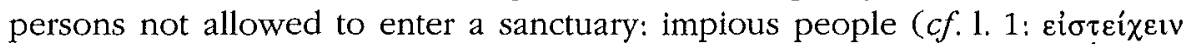
$\left.\varepsilon \cup ̉ \sigma \varepsilon \beta \varepsilon \alpha_{\alpha}\right)$, persons polluted by death, birth, and sexual intercourse (1. 2-9). Excluded were also perhaps killers (not necessarilly murderers) ${ }^{33}$ and certainly

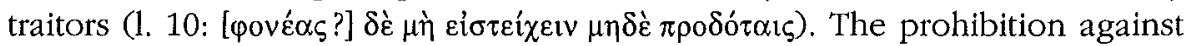
killers, if this restoration should be correct, can easily be explained in terms of pollution. The exclusion of traitors is more problematic. The nature of their treacherous behaviour (towards their friends or their country) is not specified. Traitors, too, can be regarded as $\mu 1 \alpha \rho o$, as Parker has put it, because of their

28 POLYB., IV, 35, 3. Cf. SINN, art. cit. (n. 4), p. 108.

29 Vgl. BOLKESTEIN, op. cit. (n. 2), p. 245 (without this testimony).

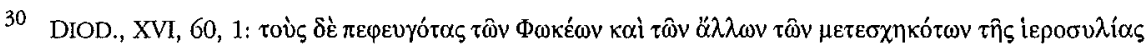

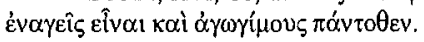

31 VON WOEß, op. cit. (n. 4), p. 68, 70f.

32 LSCG, 124 (2nd cent.).

33 Another plausible alternative is [కévolc]: see L. ZIEHEN, Leges Graecorum Sacrae. Pars Altera. Fasc. I. Leges Graeciae et Insularum, Leipzig, 1906, p. 306; cf. T. WÄCHTER, Relmbeltsvorscbriften im griecbiscben Kult, Gießen, 1910, p. 120; on the exclusion of foreigners from sanctuaries see infra, n. 36. 
"shamelessness that causes them to disregard normal constraints." 34 It is, therefore, concievable that the primary aim of this regulation was to protect the sanctuary from pollution. However, whatever its origin may have been, in effect it excluded from entrance, and consequently from protection in the sacred precinct, two groups of persons most likely to seek asylum there, killers and traitors, i.e., persons prosecuted by the families of their victims, by secular authorities, or by political opponents.

As we have seen, there is some evidence that persons who were legally prosecuted, or even condemned, were not allowed to enter a sacred precinct. The preoccupation with pollution most probably explains these measures against convicts and criminals, as it explains, for instance, measures against lodging in sanctuaries, ${ }^{35}$ But even if the primary aim of these regulations was not to prohibit the exploitation of an asylon by criminals, their result was after all the exclusion of these people from the area protected by the asylia. We should note here that there exists another group of prohibitions which are not related to asylia, but still could (theoretically) be used to keep outside a sanctuary potential suppliants: I mean regulations prohibiting the entrance of foreigners in certain sanctuaries. ${ }^{36}$ Since most asylum seekers were foreigners to the place where they sought protection (e.g., victims of civil strife and wars), these clauses effectively denied them entrance to the sanctuaries.

The aforementioned provisions most likely could provide the authorities with an excuse to lay hands on certain suppliants after they had entered the sanctuary and approached the altars. Obviously, charges of crimes committed within the inviolable area could also be used as excuses for the expulsion of suppliants. A story goes, e.g., that the philosopher Menedemos of Eretria, who was living as a suppliant in the Amphiareion at Oropos, was compelled to leave the sanctuary through a decree of the Boiotian league; some golden goblets were missing, and the philosopher was accused of stealing them. ${ }^{37}$ But there is

34 PARKER, op. cit. (n. 11), p. 5 n. 18, p. 317 n. 48. For the moral condamnation of treason see LATTE, op. cit. (n. 18), p. 69, 73f,; K. LATTE, Schuld und Sinde in der griechiscben Religion, in ARW, 20 (1920), p. 267f.; B. SNELL, Dicbtung und Gesellschaft. Studien zum Einfluß der Dichter auf das soziale Denken und Verbalten im alten Griechenland, Hamburg, 1965, p. 63-65 und Die Entdeckung des Geistes. Studien zur Entstebung des europaiscben Denkens bet den Griechen, Göttingen, $1975^{4}$, p. 65f. (treacherous friends); P.W. VAN DER HORST, The Sentences of PseudoPbocylides with Introduction and Commentary, Leiden, 1978, 123f. (on PS.-PHOKYLIDES, 1. 16-17). Treason is an insult to the gods: H.W. PARKE - D.E.W. WORMELL, The Delphic Oracle, Oxford, 1956, I, p. 380-382; A.W.H. ADKINS, Merit and Responsibility: A Study in Greek Values, Oxford, 1960, p. 110 n. 17; PARKER, op. cit. (n. 11), p. 186-188.

35 See, e.g., LSAM, $55=$ I.Knidos, 160 (Knidos, 4th cent.).

36 Cf. supra, n. 33 and further examples in WÄCHTER, op. cit. (n. 33), p. 118-123; e.g., LSCG, 110

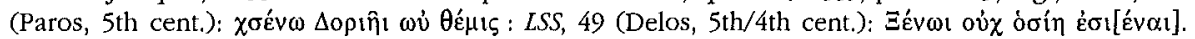
P. BUTZ, A Sacred Probibition on Delos ID 68, $A$ and B, in BCH, 118 (1994), p. 69-98 demonstrates that the latter prohibition concerns the Archegesion of Delos; she suggests that it was primarily addressed against the Athenians (ca. 404-394 or 386-377 B.C.).

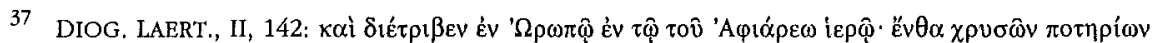

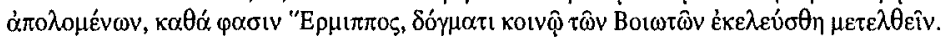


a huge difference between excuses and legitimacy. The dilemma remained. Could a secular regulation (a law or a decree) violate an unequivocal divine law which protected all suppliants, without causing the anger of gods? And this is hardly the only problem. The lex sacra from Eresos prohibited traitors from entering the sanctuary. But who decides who is a traitor and how? What one regards treason is certainly interpreted differently by the alleged traitor. Since the latter did not have the right to enter the sanctuary in the first place, we may assume that his pursuers would have an excuse to drag him out without the fear of provoking the gods' anger. But could the accused person still defend himself?

\section{Suspension of the suppliant's status through oracles}

This question brings us to the second possible solution, i.e., the oracular approval of measures against suppliants. We have seen already that Kyme had tried to shift the responsibility of a decision in the case of Paktyes to the oracle of Didyma. ${ }^{38}$ There is more and better evidence for this procedure.

The most enigmatic inscription of Arkadia, the 'Gottesurteil von Mantineia' (ca. 460), ${ }^{39}$ may be related to a procedure against suppliants. This text consists of a list of persons convicted for the murder of several men and a girl in the sanctuary of Alea and a dossier of documents related to the judicial procedure against them. Since this text has been most recently the object of an exhaustive study by $\mathrm{G}$. Thür and $\mathrm{H}$. Taeuber, who also offer a detailed presentation of previous interpretations, I will discuss here only the implications of this document for asylia, focusing on the few certain points of the document.

The inscription begins with the names of thirteen (according to Thür and Taeuber) or twelve (according to L. Dubois) men convicted for killing some men and a girl in the sanctuary of Athena Alea (1. 1-13, cf. 1. 25-28). According to Thür's persuasive interpretation the instructions for the trial (with the charge and a reference to the legal consequnces in case of conviction) are stated at the end of the inscription. ${ }^{40}$ These instructions distinguish between a defendant who is mentioned by name (Themandros) and a group of anonymous defendants. The instructions for both groups follow exactly the same pattern, as shown bellow (the differences are underlined):

38 SINN, art. cit. (n. 4), p. 79.

39 IG, V 2, 262. Most recent editions: L. DUBOIs, Recberches sur le dialecte arcadien, Louvainla-Neuve, 1986, II, p. 94-111; G. THÜR - H. TAEUBER, Prozessrechtliche Inschriften der griechischen Polets. Arkadien (SB Akad. Wien, 607), Wien, 1994, p. 75-98 no. 8.

40 THÜR, in THÜR-TAEUBER, op. cit. (n. 39), p. 86f. n. 26. 
Anonymous defendants

हi'

$\frac{\sigma l s}{i v}$

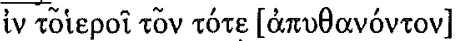

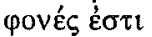

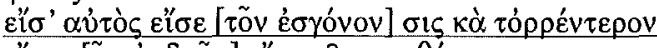

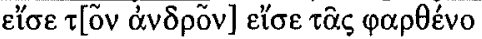

(see above)

$i v \mu \varepsilon v \varphi \grave{\varepsilon}[\varsigma \stackrel{\tilde{\varepsilon}}{\varsigma} \mathrm{\varepsilon} \alpha$

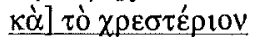

عì $\delta \grave{\varepsilon} \mu \dot{\varepsilon}$,

$i \lambda \alpha[$ ov $\tilde{\varepsilon} v \alpha 1]$
Themandros

$\varepsilon \mathfrak{i}$

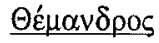

(see below)

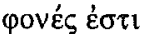

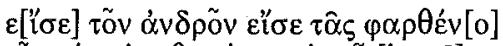

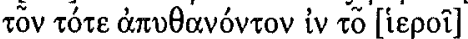

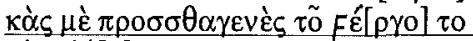

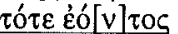

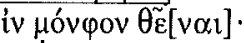

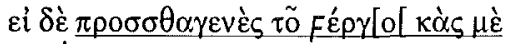
povés

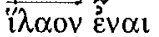

One of the many controversial issues related to this text is the question as to whether the phrase 'in the sanctuary' in the instructions for the trial against

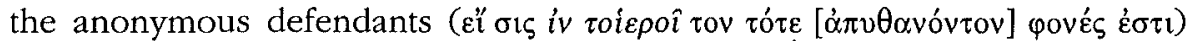
modifies the participle $\alpha \pi v \theta \alpha v o ́ v \tau o v$ (as is the case in the instructions for the trial of Themandros, i.e., "if anyone is the murderer of those who were killed then in the sanctuary") or the pronoun ois (i.e., "if anyone of the men in the sanctuary is the murderer of those who were killed then").41 At first sight the

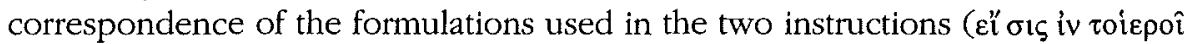

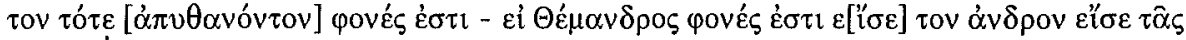

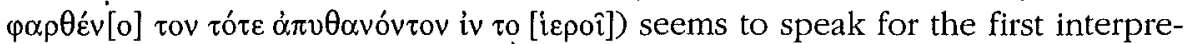
tation. However, the correspondence is not so close: In the first instruction the phrase 'in the sanctuary' pecedes the participle $\alpha \pi v \theta \alpha v$ óv $\tau$ ' instruction it follows. Furthermore, G. Thür has argued that if we accept the latter translation ('anyone of the men in the sanctuary'), the reason that a different procedure had to be followed for the anonymous defendants (in the sanctuary) and Themandros becomes apparent. The two different procedures are due precisely to the fact that all the other murderers, along with members of their families, had sought asylum in the sanctuary after their deed, whereas Themandros did not. Thür's interpretation can be strengthened by some further significant differences between the two instructions: ${ }^{42}$ a) in the case of

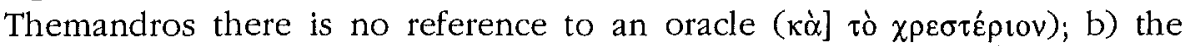
instruction for Themandros mentions the possibility (probably Themandros' allegation) that Themandros was only present in the sanctuary ( $\pi \rho \circ \sigma \sigma \theta \alpha \gamma \varepsilon v \varepsilon$ ś $)$, either during the murder or at a different point, ${ }^{43}$ but was not one of the murderers. Both differences can be explained if we accept Thür's interpre-

41 Discussion and older bibliography in THÜR-TAEUBER, op. cit. (n. 39), p. 87 n. 29.

Cf. THÜR, in THÜR-TAEUBER, op. cit. (n. 39), p. 88 n. 32.

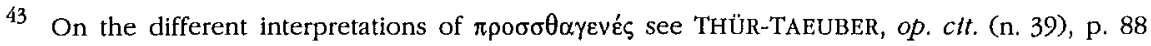
n. 33. 
tation. For Themandros' trial no reference to an oracle was necessary, since he was not a suppliant. He could be tried according to the city's laws on homicide. Only he, the only defendant who did not seek asylum in the sanctuary after the incident, could claim that he was not present in the sanctuary during the killings (or according to a different understanding of the word $\pi \rho \sigma \sigma \theta \alpha \gamma \varepsilon v \varepsilon \varepsilon_{\zeta}$, that he was only an eyewitness). ${ }^{44}$

Three further enigmas of this inscription can also be answered if we follow Thür's line of interpretation. First, the only legal consequences of the conviction

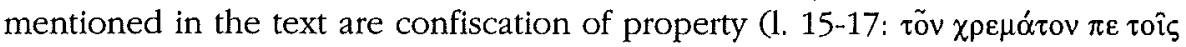

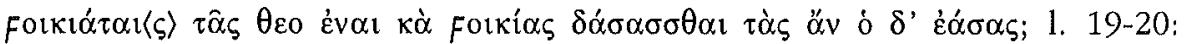

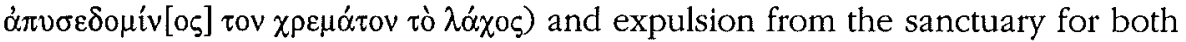

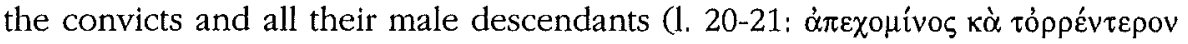

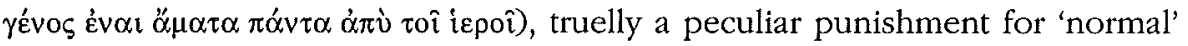
murderers. Second, the goddess is mentioned explicitly among the recipients of

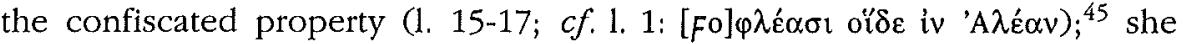
received all the movable property, whereas the immovables were to be distributed, probably among the relatives of the victims. This provision clearly indicates that the crime committed had wronged the goddess, too. And third, the various documents quoted in this dossier make allusion to two separate convictions of the defendants: a) through the goddess by means of an oracle,

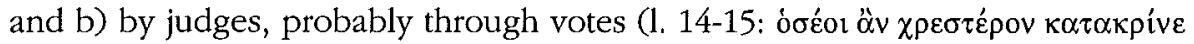

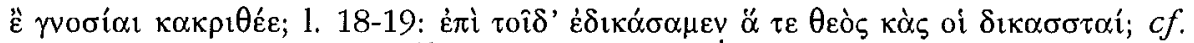

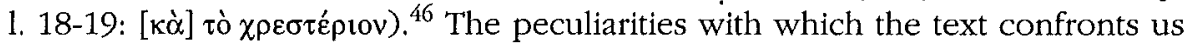
(involvement of the goddess as victim, plaintiff, and recipient of the fine, exclusion of the convicts and their descendants from the sanctuary) cannot be fully explained simply by attributing them to the fact that the murders were committed in the sacred precinct or that the victims may have been suppliants. ${ }^{47}$ These peculiarities, together with the different procedure followed for Themandros, suggest the following (admittedly speculative) scenario, Several men committed murders in the sanctuary of Alea. While the murderers -except for Themandros- were enjoying the benefits of asylia in the sanctuary, the families of their victims were crying out for revenge. The community of Mantineia was divided and powerless, while the priests saw themselves confronted with the bizarre situation of offering protection to men who had polluted the sanctuary by committing murders in the sacred precinct. Precisely this gave the solution to the problem. If the murderers could not be charged with murder by the secular authorities or by the families of the victims, they

44 THÜR, in THÜR-TAEUBER, op. cit. (n. 39), p. 88 n. 33.

45 Cf. DuBols, op. cit. (n. 39), II, p. 111: "sont redevables à l'égard d'Aléa"; THür-TAEUBER, $o p$. cit. (n. 39), p. 77: "Die Folgenden sind verurteilt zugunsten der Alea" (cf. p. 80 n. 1).

46 The interpretation of $\gamma v \omega \sigma i \alpha$ and the reconstruction of the procedure are also matters of controversy which cannot be discussed here; see THÜR-TAEUBER, op. cit. (n. 39), p. 77, 92-96.

47 Cf. THÜR-TAEUBER, op. cit. (n. 39), p. 88 n. 30. 
could be charged by the goddess for their sacrilege. Their conviction meant their exclusion from the sanctuary, i.e., terminated their status as suppliants ( $c f$. the aforementioned anecdote about Menedemos, note 37). Themandros, who was not in the sanctuary, was also convicted on the same charge, and his name appears along with the names of the others.

Such consultation of an oracle is not unique. An analogous interaction between an oracle and secular authorities is attested in Athens one century after the 'Gottesurteil von Mantineia'. The Athenian politician Kallistratos, having been accused of treason, was condemned to death by the Athenians in 361 . He fled to Methone and later to Delphi, where he received one of Apollon's puzzling oracles. Should he return to Athens, he would have fair treatment by

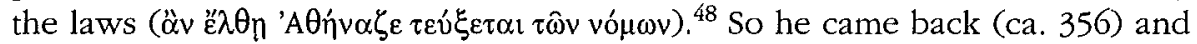
took refuge at the altar of the Twelve Gods. Nonetheless, he was put to death by the state, which interpreted the oracle's reference to the fair treatment by

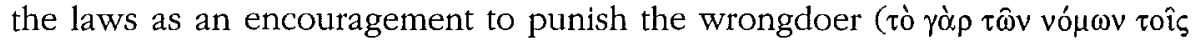

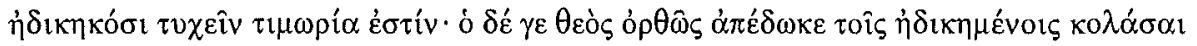

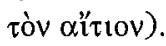

The aforementioned testimonia imply that on certain occasions authorities -civil authorities- felt themselves encouraged by oracles to disregard the rights of suppliants. A fragmentary lex sacra of the 4th century from Metropolis in Ionia with prescriptions on purity may also be related to this phenomenon. After a series of prohibitions about pollution from sexual intercourse, we find a clause about suppliants: ${ }^{49}$

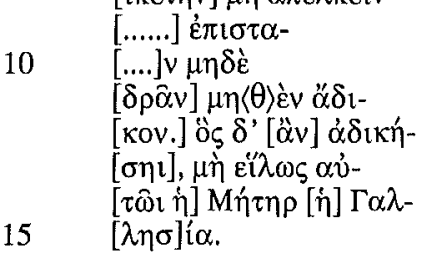

Joseph Keil and Anton von Premerstein restored the corrupt passage (1. 9-

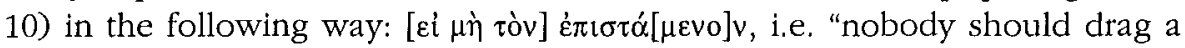
suppliant away, except for the supervisor of the sanctuary; nor should anybody wrong (i.e., a suppliant) in any way. Whoever wrongs (a suppliant), let Meter Galesia not be merciful to him." ${ }^{.50}$ An alternative restoration has been proposed

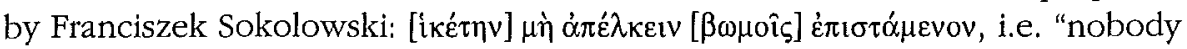

\footnotetext{
48 LYC., Leokr., 93; on this oracle see PARKE-WORMELL, op. ctt. (n. 34), II, p. $104 \mathrm{f}$.

49 LSAM, 29, 1. 8-15.

50 J. KEIL - A. VON PREMERSTEIN, Bericht uber eine Dritte Reise in Lydien und angrenzenden

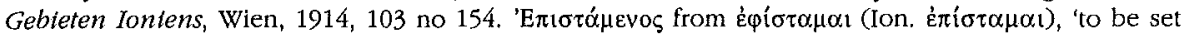
over, person in authority (LSJ, s.v., with examples).
} 
should drag a suppliant away, who/while he sits on an altar." Sokolowski's restoration is tautological. The addition "a suppliant who/while he sits on the altar" is superfluous, since the word biketes denotes exactly this action. ${ }^{51}$ On the countrary, the right of religious authorities to decide the fate of a suppliant is attested (infra). This makes the first restoration preferable, but not certain.

\section{Judicial procedures against suppliant slaves}

The evidence presented so far draws the picture of anything but a systematic, uniform, and successful effort to clear up the grievances related with unlimited asylia. Where we hoped to detect general rules, we found ad hoc reactions. This result stands in a marked contrast to the regulations about suppliant slaves. ${ }^{52}$ In their case we do find clearcut rules and unequivocal testimonia about the jurisdiction of priests in matters of asylia.

In Athens, at the latest from the classical period on, the Theseion was the preferred refuge of slaves who run away from their masters because of harsh treatment. ${ }^{53}$ Their hope was not to change their legal status, i.e., to be manumitted, but simply to be resold ( $\pi \rho \hat{\alpha} \sigma \omega$ 人iveiv). ${ }^{54}$ The evidence, reviewed recently by K.A. Christensen, implies that when the master opposed his slave's purchase, a prosecution of the master on a charge of $i \beta p i \zeta \varepsilon v v$ took place under the supervision of the priests of Theseus. ${ }^{55}$ The rôle of the priests in this procedure is not mentioned in the sources regarding Athens, but is clear in the

51 Notice, e.g., that in the Samian inscription quoted below (notes 64-65) the word ixétnড (1. 9,

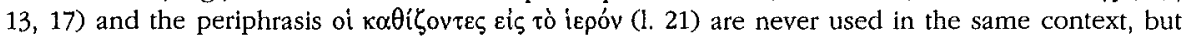
alternatively. For $\kappa \alpha \theta i \zeta_{\varepsilon l v}$ as terminus technicus for the act of supplication see e.g. LATTE, op. cit. (n. 18), p. 106f.; SINN, art. ctt. (n. 4), p. 74 with n. 68.

52 On runaway slaves see F. KUDLIEN, Zur sozialen Situation des flüchtigen Sklaven in der Antike, in Hermes, 116 (1988), p. 232-252 (with bibliography). On runaway slaves as suppliants see ibid., p. 243-245; cf. D. DAUBE, Civil Disobedience in Antiquity, Edinburgh, 1972, p. 57f.

53 For harsh or unjust treatment as an excuse for runaway slaves cf. KUDLIEN, ait. cit. (n. 52), p. $240 \mathrm{f}$.

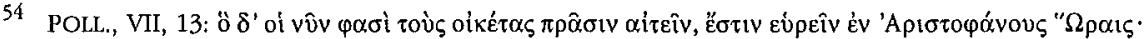

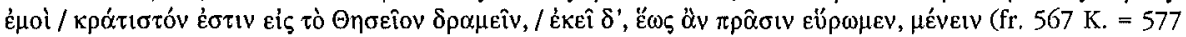

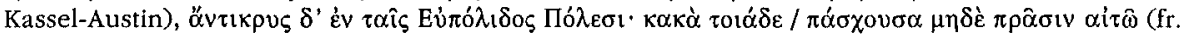

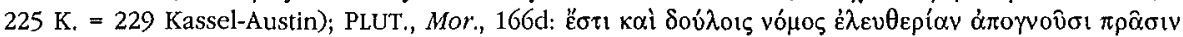

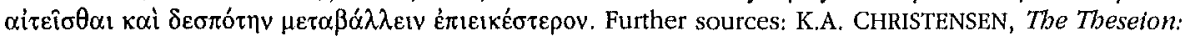
A Slave Refuge at Atbens, in AJAH, 9 (1984) [1990], p. 23-25. VON WOEß, op. ctt. (n. 4), p. 175-180 assumes that the same system applied also to Ptolemaic Egypt; $c f$. (with reservations) SCHOLL, op. cit. (n. 21), p. 303.

55 CHRISTENSEN, art. cit. (n. 54), p. 23-32, esp. 25-27. The same view had already been expressed by J.H. LIPSIUS, Das attiscbe Recht und Rechtsverfabren, Leipzig, 1912, II, p. 643; cf. LATTE, op. cit. (n. 18), p. 107; VON WOEß, op. ctt. (n. 4), p. 175-180. In Egypt, too, decisions about

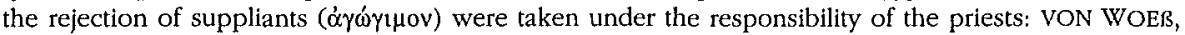

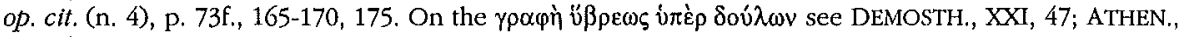
VI, 267a; cf. KUDLIEN, art. cit. (n. 52), p. 245; D.M. MACDOWELL, Demosthenes, Against Meldias (Oration [21]). Edted with Introduction, Translation, and Commentary, Oxford, 1990, p. 263-268. 
procedure about runaway slaves in the mystery inscription of Andania. ${ }^{56}$ The sacred men (iEpoí) designated an area to be a refuge for slaves. ${ }^{57}$ No person was allowed to harbor them, employ them, or offer them food. ${ }^{58}$ The priest had the exclusive responsibility in deciding which slave was to be delivered to his

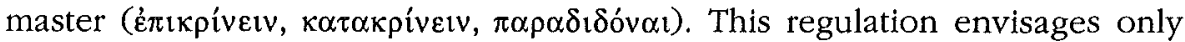
slaves from Messene. Runaway slaves from other areas were excluded from this procedure, probably for practical reasons, namely, to avoid controversies with persons from abroad claiming the ownership of suppliants. ${ }^{59}$ So, the runaway slaves from other areas as well as the runaway slaves who were not returned to their masters were either set free or (more probably) stayed in the sanctuary and served as sacred slaves ( $c f$. infra) ${ }^{60}$

Similar measures are known from Samos and Ephesos. A fragmentary letter sent by Ptolemy III Euergetes (246-222) to Samos describes, according to the persuasive interpretation by Chr. Habicht, ${ }^{61}$ a procedure which should be

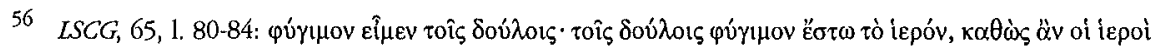

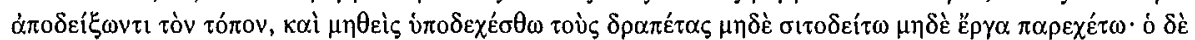

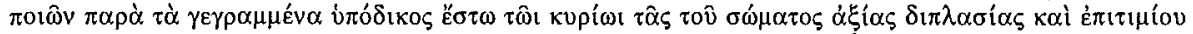

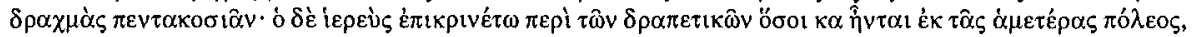

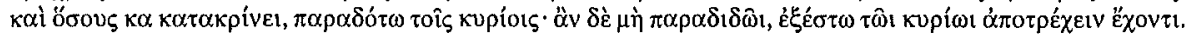
Cf. LATTE, op. cit. (n. 18), p. 107; VON WOER, op. cit. (n. 4), p. 175f. n. 3; SCHLESINGER, op. cit. (n. 4), p. 38; HABICHT, op. cit. (n. 18), p. 229; THÜR-TAEUBER, op. ctt. (n. 18), p. $220 \mathrm{f}$.

57 For parallels see SCHLESINGER, op. cit. (n. 4), p. 29 n. 4.

58 Cf. the inscription from Samos (infra, n. 63) and THÜR-TAEUBER, op. cit. (n. 18), p. 215 n. 17; SOVERINI, art. cit. (n. 13), p. 75-77. On the difficulties of suppliant slaves to supply themselves with food in Egypt see SCHOLL, op. cit. (n. 21), p. 303; cf. KUDLIEN, art. cit. (n. 4), p. 244f. G. DUNST, Zu dem samischen кú $\pi \eta \lambda o l-G e s e t z$, in $Z P E, 18$ (1975), p. 174 n. 19 disagreed with the usual interpretation of $\mu \eta \delta \dot{\varepsilon}$ है $\rho \gamma \alpha \pi \alpha \rho \varepsilon \chi \varepsilon \dot{\varepsilon} \omega$ and translated this phrase as "man soll sie in Frieden lassen". But this clause clearly includes measures limiting the rights of runaway slaves before their official acceptance. $C f$. Chr. HABICHT, Hellenistische Inschriften aus dem Heraton von Samos, in MDAI(A), 87 (1972), p. 221; L. KOENEN, The Samian Statute on אó $\pi \eta \lambda$ on in the Precinct of Hera, in $Z P E, 27$ (1977), p. 216 n. 15.

59 For a lively picture of such controversies see, e.g., PLAUT., Rudens, 706-838; cf. ACHILL. TATIUS, VIII, 1.

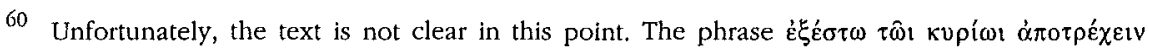
Ë $\chi 0 v \tau \imath$ can either mean "it shall be permitted for the slave to flee from the master who owns him" or "it shall be permitted for the master to run away with the slave in his possesssion": see the discussion in CHRISTENSEN, art. cit. (n. 54), p. 26f. The former interpretation is favoured by LATTE, op. cit. (n. 18), p. 107; cf. CHRISTENSEN, art. cit. (n. 54), p. 27; M.W. MEYER, The Ancient Mysteries: A Sourcebook, New York, 1987, p. 56 ("the fugitive is to be allowed to leave the master in charge of him"). The latter interpretation is accepted by THÜR-TAEUBER, op. cit. (n. 18), p. 220 n. 55 ("er muß den Zugriff des Herrn auf den 'verurteilten' Sklaven dulden"); vON WOEß, op. cit. (n. 4), p. 175f. n. 3 suspected that the slave was either resold or returned to the master, who promised to treat him better in the future. LATTE, ibid. also suggested that asylia was the primary root of manumission in the form of dedication to a deity (ibid., 105-108); $c f$. F. SOKOLOWSKI, The Real Meaning of Sacral Manumission, in HTbR, 47 (1954), p. 173-181; but see the criticism of F. BÖMER, Untersuchungen iber die Religion der Sklaven in Griechenland und Rom, Wiesbaden 1960, II, p. 14f. with n. 3 and 5.

61 HABICHT, op. cit. (n. 18), p. 226-231 no 59; cf. THÜR-TAEUBER, op. cit. (n. 18), p. 213 n. 4; SOVERINI, art. cit. (n. 13), p. 84 . 


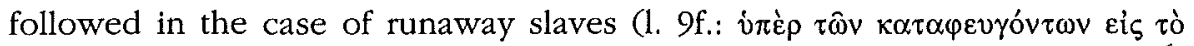
[iepòv $\sigma \omega \mu \alpha \dot{\alpha} \tau \omega v]$ ). A court (bieron dikasterion?) presided over by the neopoiai ${ }^{62}$ interrogated the fugitive slave and his master, and if the master's arguments

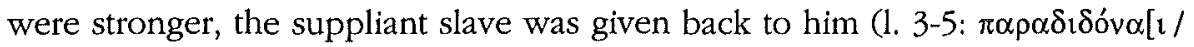

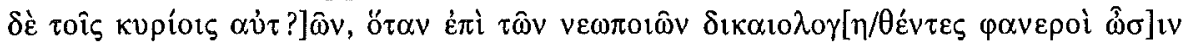
$\varepsilon \hat{\gamma} \gamma \omega \mu$ ové $\tau \varepsilon \rho \alpha \lambda \hat{\varepsilon}^{\prime} \gamma \circ \tau_{\tau \varepsilon \varsigma}$ ). At the beginning of the preserved fragment (1. 3) king Ptolemy probably refered to a similar procedure in Alexandria which should serve as a model for the Samian Heraion. Chr. Habicht is probably right sugges-

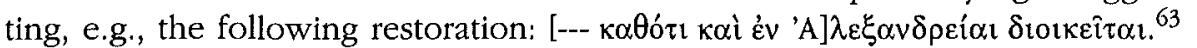
Another Hellenistic inscription from the Heraion, also published and discussed by Chr. Habicht, ${ }^{64}$ forbade traders to support suppliants (iкé $\alpha_{\alpha}$ ) and especially

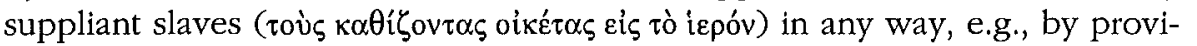
ding them with food ( $c f$. supra, note 58), employing them in their shops, or having transactions with them. ${ }^{65}$ Offences against this regulations were probably brought before a bieron dikasterion, which had jurisdiction for offences commited in the sanctuary. ${ }^{66}$ The slaves, whose masters were found guilty of an offence, may have remained in the Heraion and served as bieroi paides. ${ }^{67}$ Achilles Tatius explains in his novel Leukippe and Kleitophon the procedure followed in the Artemision of Ephesos. ${ }^{68}$ The temple was according to his report accessible only to men, virgins, and runaway female slaves, who were

62 This is the interpretation of THÜR-TAEUBER, op. cit. (n. 18), p. 221f., against HABICHT, op. ctt. (n. 18), 228f. who thought that the naopoiai had full jurisdiction, i.e., served as judges.

63 HABICHT, op. cit. (n. 18), p. 231. The restoration proposed by F. PIEJKO, Response of an Unknown City to Magnesia Concerning Her Asylia, in RSA, 17/18 (1987/88) [1989], p. 187

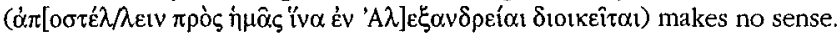

64 HABICHT, art. cit. (n. 58), p. 210-225 no. 9. Here I quote the partly revised edition of the text by THÜR-TAEUBER, op. cit. (n. 18), p. 209-212 (cf. SEG, XXVII, 545).

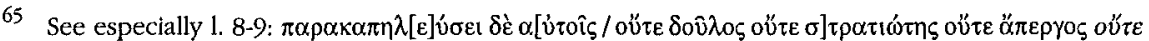

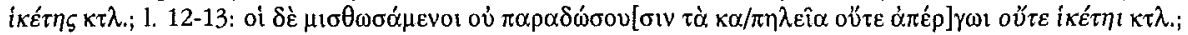

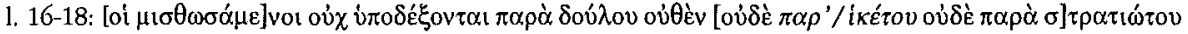

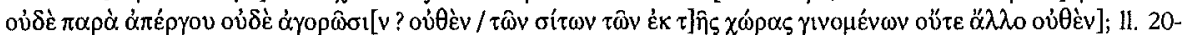

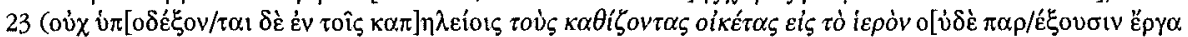

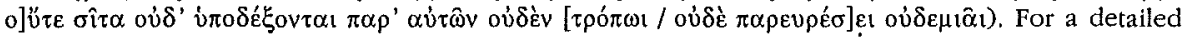
dicussion see THÜR-TAEUBER, op, cit, (n. 18), p. 212-225. For a discussion of this inscription see also DUNST, art. cit. (n. 58), p. 171-177; KOENEN, art. cit. (n. 58), p. 211-216; SOKOLOWSKI, art. cit. (n. 13), p. 143-147; SOVERINI, art. cit. (n. 13), p. 59-121.

66 THÜr-TAEUBER, op. cit. (n. 18), p. 219-222; cf. DUNST, art. ctt. (n. 58), p. 177.

67 HABICHT, op. cit. (n. 18), 230; cf. HABICHT, art. cit. (n. 58), p. 224f.; THÜR-TAEUBER, op. cit. (n. 18), p. 216 n. 36; SOVERINI, art. cit. (n. 13), p. 79 f.

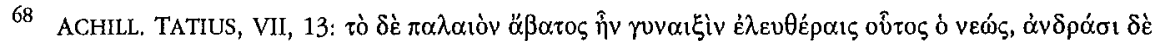

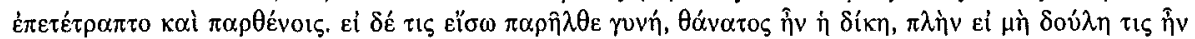

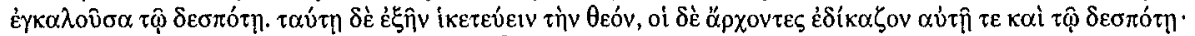

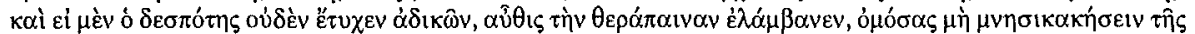

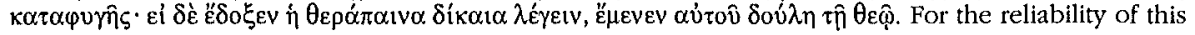
information see the remarks of DEBORD, op. cit. (n. 12), p. 81 and 352 n. 38; as he points out, PLUT., Alex., 42 and CIC., Verr., 1, 85 may reflect this practice; $c f$. LATTE, op. cit. (n. 18), p. 107f. On the asylia of the Ephesian Artemision see also VAN BERCHEM, art. cit. (n. 4), p. 24-26. 


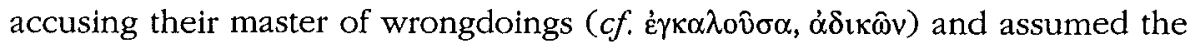
status of suppliants. The case of the slave was decided by a court presided over by magistrates, ${ }^{69}$ and if the master was found to have committed no injustice against her, he took the woman back; if not, the suppliant remained in the sanctuary as the goddesses' slave. This explicit evidence for runaway slaves remaining as sacred slaves in the sanctuary where they had found refuge may possibly explain the grave stones of bieroi found near the sanctuary of Poseidon at Tainaron, known to have served as a place of refuge for helots, at least in one instance, i.e., during their great revolt in the 5 th century. ${ }^{70}$ These sacred slaves may have been runaway helots, who had found asylia in Poseidon's sanctuary.

For the judiciary procedures which decided the fate of suppliant slaves the

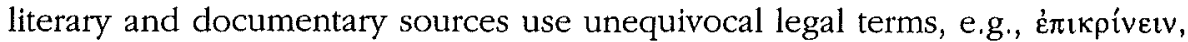

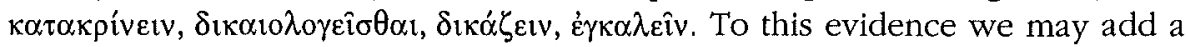
more problematic testimony, an early legal inscription from Gortyn (early 5 th century), which seems to have forbidden the purchase of suppliant slaves $\left(v \alpha \varepsilon v v^{\prime} \tau \alpha\right)$ for one year (after they had taken refuge in a sanctuary). ${ }^{71}$ It has been suggested, that this regulation gave the slave and the master the opportunity to come to an arrangement, perhaps with arbitration of the priest. ${ }^{72}$

The development of special -and more or less uniform- regulations in the case of suppliant slaves came about for a variety of reasons. In their case the problem was obviously most pressing and, given the significant economic and social implications, a uniform solution was needed urgently. In addition, the

69 THÜR-TAEUBER, op. cit. (n. 18), p. 221 have demonstrated that this is how we should

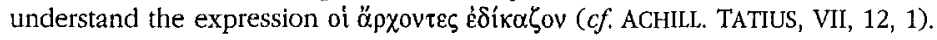

70 For the epitaphs of blerol see J. DUCAT, Esclaves au Ténare, in M.-M. MACTOUX - E. GENY (eds.), Mélanges P. Lévêque 4. Religion, Paris, 1990, p. 192f.; BÖMER, op. cit. (n. 60), II, p. $153 \mathrm{f}$. doubts that these bieroi were slaves; D. PLACIDO, Los lugares sagrados de los bilotas, in J. ANNEQUIN - M. GARRIDOTTORY (eds.), Religion et antbropologie de l'esclavage et des formes de dépendance, Paris, 1994, p.127-145. On the sanctuary at Tainaron as asylon see, e.g., BÖMER, op. cit. (n. 60), II, p. 18f.; but see the reservations of J. DUCAT, art. cit., p. 184-186 and ID., Les bilotes, Paris, 1990 , p. $130 f ., 183-187, c f$. p. $11,25 f$., on the question if the Spartan helots had any special relations with this sanctuary. For asylum seekers serving as enkatocbol in Egypt cf. DELEKAT, op. cit. (n. 17), p. 71-85, 94f. (partly speculative); cf. already VON WOEß, op. cit. (n. 4), p. 140-164 and 179 (fugitive slaves as hierodouloi). $C f$. also the case of a person who found asylon in a sanctuary in

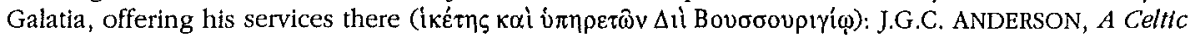
Cult and Two Sites in Roman Galatia, in JHS, 30 (1910), p. 164 no. 2 (3rd cent. A.D.): on this text see also DEBORD, op. cit. (n. 12), p. 355 n. 72, 453 n. 187.

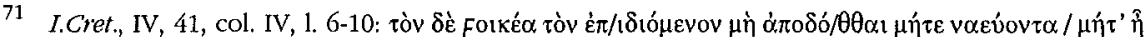

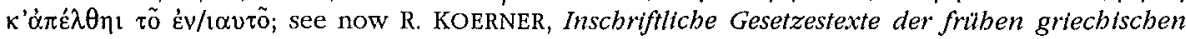
Polis, Köln-Wemar-Wien, 1993, p. 384-386 no. 128 (text, commentary, and older bibliography). Cf. I.Cret., IV, 72, col. I, 1. 39-49 = KOERNER, op. cit., p. 454f., 462f. no. 163. Cf. LATTE, op. cit. (n. 18), p. 107. Another Gortynian regulation about fugitive slaves: I.Cret., IV, 47, 1. 31f. = KOERNER, op. cit., p. $408 \mathrm{f} ., 411$ no 138.

72 KOERNER, op. cit. (n. 71), p. 386. For cases of negotiations see supra, n. 23. Cf. SCHLESINGER, op. cit. (n. 4), p. 41. The reconciliation between runaway slave and master is mentioned by PHILO

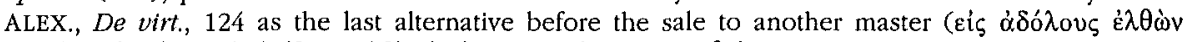

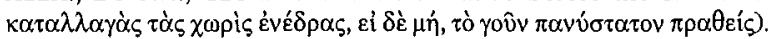


presence of suppliant slaves in sanctuaries could be easily reconciled with the current divine and secular law. On the one hand, they were not regarded as polluted, and on the other, their supplication did not change their legal condition but only their owner. There is no evidence that they were manumitted; they were either sold to another master, or returned to their owner, or were allowed to stay in the sanctuary as slaves of the god.

\section{Asylia: The right of the 'wronged'}

Despite the diverse character of the evidence on limitations of asylia, this evidence supports at least one clear conclusion. At the latest from the early 5th century, asylia and supplication were increasingly becoming claims which ought not be respected automatically, but only after a close examination of each individual case. Sacred and civil authorities responsible for sanctuaries claimed for themselves the right to take the final decision of accepting, rejecting, or expelling suppliants. In the case of slaves, only the victims of cruel violence were granted the right to remain in the sanctuaries; as D. Daube has pointed out, the supplication of slaves was per se morally justifiable. ${ }^{73}$ Similarly, in the case of free persons a distinction seems to have been made between those who sought asylia because they had been wronged (oi $\alpha \delta$ เ wanted to avoid further injuries, and those who fled to sanctuaries after a crime, in order to avoid the punishment ordered by secular law. We may notice how often the notion of $\alpha \delta \varepsilon \varepsilon \hat{\alpha} \sigma \theta \alpha \imath$ appears in our sources in the context of supplication. ${ }^{74}$ It seems that the emphasis on the idea that a suppliant is the victim of injustice was relatively recent, attested for the first time in the 5th century. The idea that asylia should not be provided anymore unconditionally and automatically to anyone who had reached a sacred precinct is expressed indirectly also in Attic drama, which often presents suppliants explaining why they are seeking asylum and underlining the fact that they bave been wronged. They do not simply demand protection secured by divine law, but defend their claim with arguments which resemble forensic speeches. I reproduce here only Kreousa's advocacy in Euripides' 'Ion': "I only try to slay you, an enemy to my

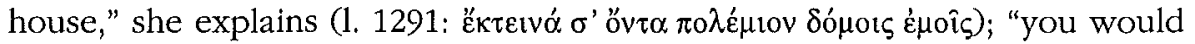

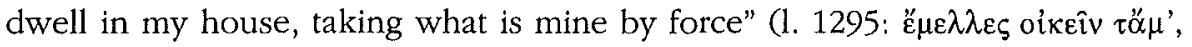

73 DAUBE, art. cit. (n. 52), p. 57; KUDLIEN's disagreement (art. cit. [n. 52], p. 243) disregards the aforementioned evidence.

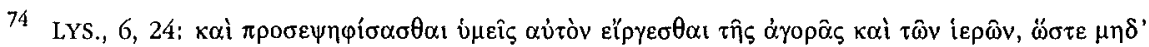

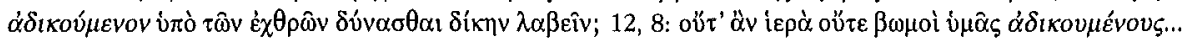

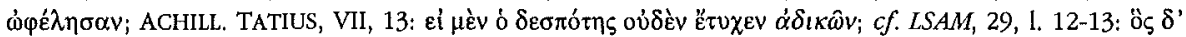

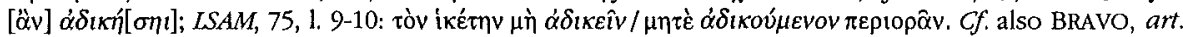

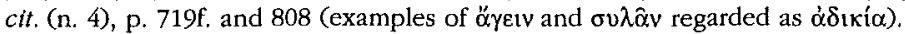




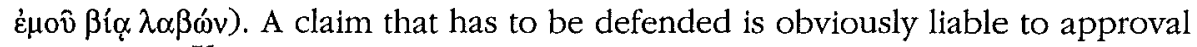
or rejection. ${ }^{75}$

Of decisive importance for our understanding of the reasons why the Greeks changed their attitude toward the unlimited and invariable asylia is a passage in Thucydides (IV, 97-98). The defeated Athenians (424 B.C.) had fortified Apollon's sanctuary at Delion. Theban envoys demanded their departure, appealing to the common Greek custom to abstain from sanctuaries and pointing out that the Athenians were polluting the holy place. In their response the Athenians assumed the position of suppliants explaining that they had not entered the sanctuary with the intent to harm it, but rather in order to defend

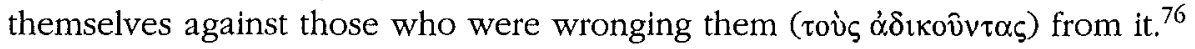
"Altars are a refuge in cases of involuntary misdeeds ( $\tau \hat{\omega} v$ ákovoí $\omega v$ $\dot{\alpha} \mu \alpha \rho \tau \eta \mu \alpha \dot{\alpha} \omega v)$, and transgression is a term applied to those who do evil without compulsion and not to those who are driven by misfortunes to some act of daring." ${ }^{77}$ Thucydides limits the right to asylia to persons who were either

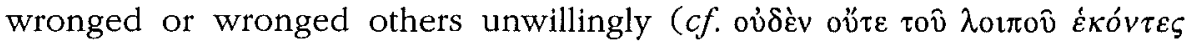

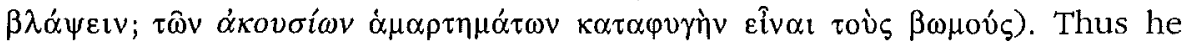
applies to asylia an important innovation of archaic law, the differentiation betwen intention, responsibility, and accident, attested for the first time in Drakon's laws on homicide. ${ }^{78}$ This innovation was gradually, reluctantly, and only sporadically adopted by sacred law, too. A lex sacra from Kleonai from the first half of the 6th century explicitly states that persons who kill in self-defence

75 For other examples see SCHLESINGER, op. cit. (n. 4), p. 39f. Based on this evidence SCHLESINGER, op. cit, p. 43 even suggested that in Athens the popular assembly decided about the acceptance of suppliants; this assumption cannot be supported by the documentary sources.

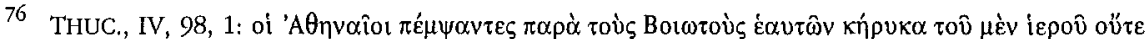

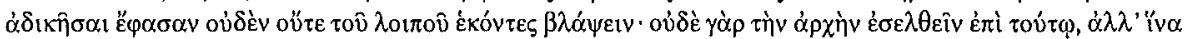

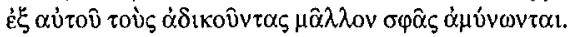

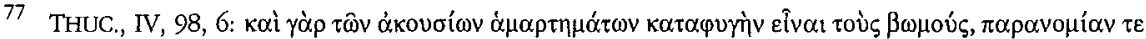

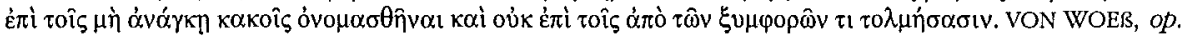
cit. (n. 4), p. 173 n. 1 thought that the view expressed by Thucydides was generally accepted in Greece. This is hardly the case; Thucydides reflects a relatively late stage of development. For the Near Eastern view that asylia applies only to unintentional crimes see VON WOEß, op. cit., p. 173

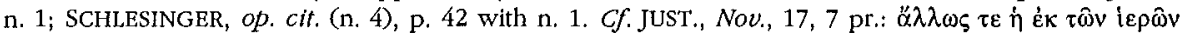

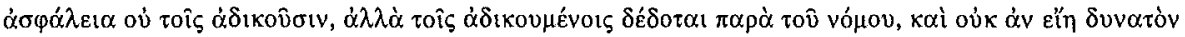

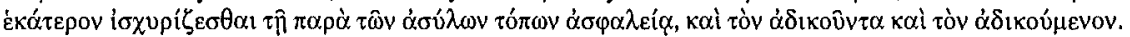

78 On this innovation see R. MASCHKE, Die Willenslebre im grlecbischen Recht, Berlin, 1926, p. 77f., 150-159; D.M. MACDOWELL, Athentan Homicide Law in the Age of the Orators, Manchester, 1963, p. 60-69, 125f.; ADKINS, op. cit. (n. 34), p. 304-308, 319-328; J. TRIANTAPHYLLOPOULOS, Das

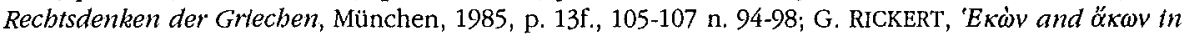
Early Greek Thought, Atlanta, 1989, esp. p. 76, 86; M. GAGARIN, Bouleusis in Athenian Homtcide Law, in G. NENCI - G. THÜR (eds.), Symposion 1988. Vorträge zur griecbiscben und bellenistscben Recbtsgescbicbte, Stena-Pisa, 6.-8. Junt 1988, Köln-Wien, 1991, p. 81-99. Cf. A. DIHLE, Die goldene Regel. Eine Einfilbrung in die Gescbicbte der antiken und fribchrlstlichen Vulgaretbik, Göttingen, 1962, p. 15-18, 48-52; A. DIHLE, Die Vorstellung vom Willen $m$ der Antike, Göttingen, 1985, esp. 31-78. 
or who have slain a cursed person are not miaroi; $;^{79}$ and from the middle of the 4 th century, under the influence of this development, the leges sacrae increasingly demand not only the external purity of the body, a purity independent of intentions, but also the purity of the mind. ${ }^{80}$

The new understanding of miasma and the transformation of asylia from a protection which is offered automatically and unconditionally, to an institution for which ethical and legal consideration apply, should be seen as part of the same development. In both cases we are dealing with conditions established automatically, as soon as a person performs a certain activity. In both cases, originally, questions of guilt and intention did not play any rôle. In both cases the more differentiated understanding of guilt initiated a significant change. Asylia transformed itself from a right which had to be offered automatically to any person who claimed it within a sacred precinct to a privilege which should be granted only if certain moral and legal conditions were fulfilled; similarly miasma was increasingly regarded a state of the mind, and not an automatically transmittable taint. ${ }^{81}$ Lastly, in both cases the Greeks remained inconsistent. Relics of the old concepts of asylia and miasma can be found in the literary and documentay sources until imperial times. ${ }^{82}$

\section{Conclusions}

The Greeks were, in general, extremely reluctant about the introduction of laws that might limit or even regulate asylia, probably due to their conviction that divine law is superior to secular authority ( $c f$. infra). However, from the late 7 th century secular law, especially the legislation on homicide, introduced a fine differentiation in the notion of guilt, which gradually influenced the sacred law. The idea that divine protection could not be offered automatically and invariably to criminals began to prevail. Already in the 5th century we encounter in Euripides and Thucydides the first voices endorsing the view that supplication is the right only of the 'wronged'. From the early 5th century we also find in the documentary sources indications of an increasing preoccupation with the exploitation of asylia by criminals. The testimonia $(\$ 2-3)$ do not reveal a systematic approach to this issue, but rather take the form of exceptional, ad

79 LSCG, 56; see now KOERNER, op. cit. (n. 71), p. 93-95 no. 32; for this development cf. PARKER, op. cit. (n. 11), p. 110-114.

80 See A. CHANIOTIS, Reinbeit des Koppers, Reinbeit des Sinnes in den griechlscben Kultgesetzen. Ein epigrapbischer Beitrag zur griecbischen Auffassung von Schuld, in J. ASSMANN - Th. SUNDERMEIER, Scbuld und Identität (Studien zum Versteben fremder Religionen), Gütersloh (forthcoming); cf. PARKER, op. cit. (n. 11), p. 320-324.

81 Several early epigraphic sources for this idea: PORPH., De abstinentia, II, 19, 5; CLEM. ALEX., Stromatets, V, 1, 13, 3 (inscription at the Asklepieion of Epidauros); M. ERRINGTON, Inschriften von Euromos, in Epigranat, 21 (1993), p. 29f. no 8 (Euromos, sanctuary of Zeus Lepsynos, 2nd cent.); $c f . L S C G, 129$ (Eresos, 4th cent.); I.Cret., I, xxiii 3 (Phaistos, 2nd cent.).

82 For asylia see supra, n. 10. For miasma see, e.g., LSCG, 55 (Athens, 2nd cent A.D.). 
hoc measures to face a situation threatening to get out of control. As we may infer from later sources, these measures (appeal to oracles, impediments against potential intruders) failed to regulate asylia effectively (supra, notes 10 and 15). Only in the case of runaway slaves we do find clear and unequivocal rules. The priests (Andania, Athens?) or magistrates (Ephesos, Samos) examined the charges of the slaves against their masters and decided whether a slave was to be returned to the master, resold, or kept in the sanctuary as a sacred slave $(\$ 4)$.

Even the efforts of Greek cities to set certain limits to an institution deeply rooted in religious customs never questioned the supremacy of divine over secular law. This conviction is clearly expressed in the legal sources, e.g., in Lysias, who in his speach against Eratosthenes castigated the thirty tyrants for violating the rights of suppliants, exactly because "they conceived their own authority ( $\left.\dot{\alpha} \rho \chi \eta^{\prime}\right)$ being more secure $\left(\beta \varepsilon \beta \alpha\right.$ to $\left.\varepsilon_{\varepsilon} \rho \alpha\right)$ than the vengeance of gods." ${ }^{\prime 3}$ Consequently, even the regulations for the limitation of asylia usually had a religious foundation; e.g., they aimed at protecting sanctuaries from pollution, they were approved by oracles, or they engaged religious personnel.

Under these conditions, the bitter criticism of Ion against this divine law

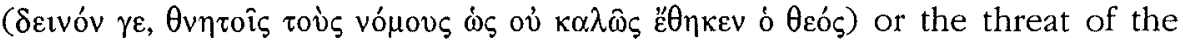

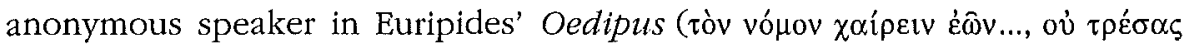
$\theta \varepsilon o$ ó $)$ seem, at first sight, to break the constraints respected by the Greeks, This impression is, however, misleading. In the further development of the Ion (perhaps also of the Oedipus) a surprise awaits the protagonist. Had Ion violated the asylum, he would have killed -unknowingly- his own mother. ${ }^{84} \mathrm{~A}$ seemingly logical and just regulation would have allowed Ion to committ the worst crime, matricide, it would have opened the way to an even greater injustice. Here, too, the divine law reveals itself superior to human considerations, and the insight of the changable and unpredictable fate of men impedes the restriction of one of the most humane institutions of the Greeks.

New York University

Angelos CHANIOTIS

Faculty of Arts and Science

Department of Classics

25 Waverly Place

New York NY 10003-6790

U.S.A.

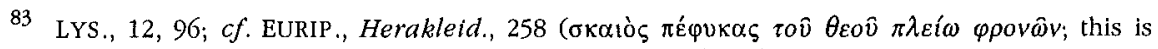
Demophon's reaction to the herolds demand to deliver suppliants).

84 BURNETT, art. cit. (n. 3), p. 99 and n. 36 (Ion "delivers his speech against the sacred nomos of asylum in circumstances arranged to demonstrate the enormity of his attempt to judge what heaven has established, for the audience knows that if he follows his secular sense of justice and breaks the 'senseless' divine law he will cause the death of his own mother"); MIKALSON, op. cit. (n. 2), p. 75 . 